\title{
Unkarin kielen yliopisto-opetuksesta Suomessa $^{1}$
}

Helsingin yliopistossa on annettu tieteellistä suomen ja sen sukukielten opetusta noin 115 vuotta, M. A. Castrénin tultua ensimmäiseksi suomen kielen ja kirjallisuuden professoriksi v. 1851. Aivan näin kauan ei meillä kuitenkaan ole opetuksessa kiinnitetty suoranaista huomiota u $\mathrm{nkar}$ in kieleen. Castrénin varhaisen kuoleman jälkeen (1852) tosin Elias Lönnrot hoiti oppituolia noin 9 vuotta (1853-62), ja hänen tiedetään olleen kosketuksissa joihinkin unkarilaisiin oppineisiin, mutta hän oli kuten tunnettua varsinaisilta opinnoiltaan lääkäri ja monista filologisistakin ansioistaan huolimatta enemmän suomen kirjakielen käytännöllinen kehittäjä kuin varsinainen kielentutkija. Vasta kolmas oppituolin haltija August Ahlqvist (professorina 1863-88), joka oli omakohtaisesti tutkinut mm. vogulia ja ostjakkia, oli aktiivisesti kiinnostunut myös unkarin kielestä. Tunnettua on, että hän harjoitti kielitieteellisiä opintoja Unkarissa (1862), oppi unkarin kieltä ja julkaisi 1863 ruotsinkielisen tutkimuksen Om Ungerska språkets förvanditskap med Finskan. Ahlqvist oli kuten tiedetään myös kirjeenvaihdossa mm. Pál Hunfalvyn ja József Budenzin kanssa. Hänen professorikautenaan annettiin ensi kertaa varsinaista unkarin kielen opetustakin Suomen yliopistossa. V. 1869 nimitettiin näet 'suomen ja unkarin kielen dosentiksi' tohtori Oskar Blomstedt (synt. 1833), joka oli v. 1865-66 käynyt opintomatkalla mm. Unkarissa ja julkaissut dosentuuria varten väitöskirjan 'Halotti Beszéd ynnä sen johdosta vertailevia tutkimuksia unkarin, suomen

\footnotetext{
1 Esitetty unkariksi Debrecenin yliopiston Magyar Müvelödési Tanfolyam -kursseilla heinäkuussa 1965 ja julkaistu aikakauskirjassa Magyar Nyelvjárások XII (Debrecen 1966).
} 
ja lapin kielissä' (1869). Blomstedt ryhtyi heti syyslukukauden alusta 1869 pitämään ylioppilaille unkarin kielen kurssia. Valitettavasti Blomstedtin varhainen kuolema (18. 2. 1871) keskeytti tämän ensimmäisen opetuksen kovin pian ja lähes 10 vuodeksi. Vasta syyslukukaudella 1880 näet alkoi sitten Antti Jalavan (synt. 1846) toiminta yliopiston ensimmäisenä, tosin vain sivutoimisena unkarin kielen lehtorina (pääammatiltaan hän oli senaatin suomen kielen kääntäjä). Tätä opetustehtävää Jalava hoiti kolme vuosikymmentä, v. 1909 tapahtuneeseen kuolemaansa asti. Anttị Jalavalla, joka kävi monesti Unkarissa ja oli hyvin oppinut unkarin kielen, on tähän päivään asti suurimmat ansiot Unkarin kansan ja kulttuurin tunnetuksi tekijänä Suomessa. Tätä uhrautuvaa harrastustaan hän suoritti paitsi yliopiston opettajana myös erittäin aktiivisena sanomalehtimiehenä, useiden Unkaria esittelevien suomenkielisten teosten toimittajana ja unkarilaisen kaunokirjallisuuden suomentajana.

Jalavan kuolemaa seurasi puolentoista vuosikymmenen pituinen välikausi, jolloin säännöllinen unkarinopetus yliopistostamme puuttui. Onneksi oli jo v. 1892 suomen kielen professuurin rinnalle perustettu suomalais-ugrilaisen kielitieteen oppituoli, ja tämän uuden viran haltijat tietenkin luennoivat kyllä unkaria, milloin se muun tieteellisen opetuksen ohessa kävi päinsä. Varsinkin Heikki Paasonen (professorina Arvid Genetzin jälkeen 1904-1919) ja hänen seuraajansa Yrjö Wichmann (1920-32) olivat kumpikin hyvin perehtyneet unkarin kieleen myös käytännöllisesti (molemmat olivat, kuten tunnettua, naimisissakin unkarittaren kanssa); Wichmann luennoi joskus jopa Unkarin kirjallisuudestakin.

Vihdoin Suomen itsenäisyyden ensimmäisen vuosikymmenen lopulla (1925) yliopistoon perustettiin vakinainen unkarin kielen lehtoraatti, jonka haltijan tulee olla syntyperäinen unkarilainen. Vuodesta 1926, jolloin ensimmäiseksi lehtoriksi nimitettiin tohtori Gyula Weöres, Helsingissä on säännöllisesti annettu käytännöllistä unkarin kielen opetusta ja myös luennoitu Unkarin kirjallisuudesta. Nykyinen lehtori István Nyirkos (1962-) on järjestyksessä neljäs vakinainen tämän viran haltija. Lehtorien unkarin kielen alkeiskurssin lisäksi opetusohjelmaan on samanaikaisesti yleensä kuulunut myös suom.ugr. kielitieteen professorin esittämä kielihistoriallinen luentosarja; niissä on pidetty silmällä varsinkin sellaisia seikkoja, joissa unkarin kieli on omiaan valaisemaan suomen kielen esihistoriaa. Näistä luen- 
noista huolehti 1930-luvulta lähtien henkilökohtainen ylimääräinen professori Artturi Kannisto, tunnettu vogulin kielen tutkija ja harras Unkarin ystävä (kuoli 1943). Vuosina 1949-65 ne ovat erityisten olosuhteiden vuoksi joutuneet tilapäisesti minun tehtäväkseni, vaikka en valitettavasti suinkaan ole sen paremmin unkarin kuin minkään muunkaan suomen etäsukukielen erikoistuntija.

Unkarin kielen lehtorinviran perustamisesta lähtien, siis jo noin 40:n viime vuoden ajan, Helsingin yliopistossa (ja sittemmin myös Turun Yliopistossa ja Jyväskylän korkeakoulussa ${ }^{2}$ ) on ollut voimassa säädös, jonka mukaan filosofian kandidaatin tutkinnossa suomen kielen ylimmän eli ns. laudatur-arvosanan vaatimuksiin kuuluu tietyn laajuinen kurssi jotakin ns. etäsukukieltä, siis ei-itämerensuomalaista kieltä. ("Suomalais-ugrilaisen kielitieteen" arvosanojen kohdalla vastaavat vaatimukset luonnollisesti ovat laajemmat ja monipuolisemmat; unkarin kieli on siinä pakollinen kahden vaihtoehtoisen etäsukukielen ohella.) Opiskelija saa itse valita näistä kielistä minkä tahansa. Valinta riippuu ymmärrettävästi suurelta osalta siitäkin, minkä etäsukukielen opetusta milloinkin on ollut sopivasti tarjolla. Eri aikoina ovat olleet suosiossa varsinkin lappi ja mordva, jotka suomen kielen kannalta tietenkin kuuluvat lähimpiin etäsukukieliin ja joita viime aikoina ovat luennoineet sellaiset spesialistit kuin Paavo Ravila ja Erkki Itkonen, mutta esim. Yrjö Wichmannin aikana olivat useas-

2 Korrehtuuritisäys. Turun Yliopistossa unkarin kielestä ovat luennoineet: Aarni Penttilä (ylimääräisenä opettajana) kevätlukuk. 1926, Iukuv. 1928-29 ja lukuv. 1930-31, Paavo Ravila professorikautenaan, Osmo Ikola professorikautenaan 1950-luvun alkupuolella, Paavo Siro apulaisprofessorina 1950-Iuvun lopulla ja ,1960-luvun alussa, Matti Liimola suom.-ugr. kielentutkimuksen professorina $\nabla:$ sta :1964 joka vuosi; lehtorinopetusta ovat antaneet: teol. tri Rudolf Molnár kevätlukukaudesta 1957 lähtien, v:sta 1960 lehtorinviran hoitajana (vain puolta virkaa hoitaen), ja tolıtori László Jakab v:sta 1966 täysitoimisena lehtorina. - Jyväskylän kesäyliopistossa ja v:sta 1936 Kasvatusopillisen korkeakoulun kesälukukausina unkaria on opetettu melko säännöllisesti. Aluksi alkeiskursseja piti prof. Aarni Penttilä, myöhemmin unkarilaiset prof. Gyula Zolnai (1926), tri Gyula Weöres (1928), useina peräkkäisinä kesinä prof. György Lakó, välillä prof. Bálint Csúry (1936). Sodan jälkeen Jyväskylässä on alkeisopetuksen lisäksi ollut kielihistoriallisia unkarin kursseja, Iuennoitsijoina prof. Lakó, tohtorit ödön Lavotha ja Ferenc Kovács sekä professorit István Papp ja Béla Kálmán; viimeksimainittu toimi koko kevätlukukauden 1964 vierailevana professorina luennoiden unkarin lisäksi vogulia. (Tiedot Turun osalta prof. Osmo Ikolan, Jyväskylän osalta prof. Aarni Penttilän ystävällisesti välittämiä.) 
ti tarjolla myös hänen erikoisalansa tšeremissi, syrjääni tai votjakki. Suhteellisesti suosituin on kuitenkin aina ollut unkarin kieli, mikä tietysti johtuu siitä, että se on suurimman suom.-ugr. kansan ja rikkaan kirjallisuuden kieli. Vaatimuksiin kuuluu, että kaksi lukukautta kestävän ja kaksi viikkotuntia käsittävän unkarin kielihistoriallisen kurssin osanottajien on ollut joko aikaisemmin tai rinnakkain seurattava myös unkarin kielen lehtorin alkeiskurssia, joka samaten kestää kaksi lukukautta ja käsittää 2 tụntia viikossa. Näin ollen unkarin kielen valinneelta opiskelijalta kuluu tämän sukukielen opetuksen seuraamiseen kaksi kentaa niin paljon aikaa kuin jonkin muun etäsukukielen, esim. lapin tai mordvan valinneelta. Tästä huolimatta unkarin kielen kuulijoita on Helsingin yliopistossa 15:n viime vuoden kuluessa ollut vuosittain keskimäärin 40-50 eli enemmän kuin muiden etäsukukielten opiskelijoita yhteensä.

Julkisessa kulttuuripoliittisessa keskustelussa on aika ajoin asetettu kysymyksenalaiseksi, onko tarkoituksenmukaista, että tulevia äidinkielenopettajia vaaditaan kuluttamaan kallista aikaansa tutustumalla johonkin, historiallisesti tosin "sukukieleksi" todettuun mutta itse asiassa ventovieraaseen pikkukieleen. Varsinkin oppikoulupedagogien on kuultu kysyvän, eikö tuollaiseen kovin teoreettiseen akateemiseen askarteluun käytetty energia olisi parempi kohdistaa joidenkin opettajan arkipraktiikkaa lähempänä olevien aiheiden käsittelyyn. Tämmöisiä epäilyjä torjuttaessa on yliopiston taholta tavallisesti katsottu riittäväksi vedota siihen, äsken jo mainitsemaani näkökohtaan, että sukukieleen perehtyminen avaa perspektiivejä opiskelijan äidinkielen esihistoriallisiin vaiheisiin. Tähän sinänsäkin tietysti asialliseen perusteluun haluaisin lisätä toisen, jota en ole huomannut täs s ä yhteydessä esitetyn. Tarkoitan sitä merkitystä, mikä käsittääkseni on rakenteeltaan hyvin erilaiseen kielisysteemiin tutustumisella opiskelijan yleisling vistisen tietämyksen avartumiselle ja syvenemiselle. Tunnettuahan on, että siellä, missä yliopiston opetus- ja tutkimusohjelmaan kuuluu ns. yleinen kielitiede, on tavallisesti kurssivaatimuksissa kohta, joka velvoittaa opiskelijaa perehtymään johonkin hänen omalle kielikunnalleen vieraaseen kieleen - mitä vieraampaan, sitä parempi. Tietääkseni esim. Kööpenhaminan yliopistossa, jossa yleisellä kielitieteellä on kunniakkaat perinteet, on suomen kieltä juuri sen ei-indoeurooppalaisuuden takia jo Rasmus Raskin ja sittemmin Vilhelm Thomsenin päivistä 
lähtien jonkin verran harrastettu tuollaisena lingvistin näköpiiriä avartavana oppiaineena. Arvattavasti myös niillä, jotka ovat ulkomailla joutuneet opettamaan unkaria, on vastaavanlaisia kokemuksia heidän kieltään kohtaan tunnetusta mielenkiinnosta. Helsingin yliopistosta (kuten valitettavasti kaikista muistakin Suomen yliopistoista) puuttuu toistaiseksi yleisen kielitieteen oppituoli. Aloite sen perustamiseksi on kyllä parastaikaa vireillä. ${ }^{3}$ Yleisestä kielitieteestä toivotaan tulevan hyödyllinen sivuaine mm. juuri äidinkielen opiskelijoille, joiden näköalat usein kieltämättä jäävät liian ahtaasti oman kielen, sen murteiden ja lähisukukielten piiriin rajoittuviksi. Mutta juuri äidinkielen yliopisto-opintoihin sinänsä sopisi paremminkin kuin esim. germaaniseen, englantilaiseen tai klassilliseen filologiaan sisällyttää kohtuullinen erä yleistä kielitiedettä, koska äidinkielen rakenteen pääpiirteet ovat asianomaisille jo alun alkaen tutut, kun taas vieraiden filologiain pelkkä grammaattinen ja leksikaalinen omaksuminen vaatii paljon suuremman osan opiskelijain tarmosta.

Tällaisestakin näkökulmasta katsoen on käsittääkseni suomen kielen opiskelijoille Helsingin yliopistossa ollut - systemaattisen yleislingvistisen opetuksen puuttuessa - avartava merkityksensä sellaisen hyvin kaukaisen ja hyvin erilaisen sukukielen kuin unkarin harrastamisella. Sillä sukulaisuudestaan huolimatta unkarilla on suomalaiselle myös monenlaista vi erauden viehätystä, koska ne vähintään neljä vuosituhatta, joiden ajan esivanhempamme ovat eläneet erossa toisistaan, ovat ehtineet suuresti loitontaa heidän yhteistä kieliperintöään kumpaakin omaan suuntaansa. Täten unkarissa oikeastaan on suomalaiselle tutustujalleen varsin monta sellaista vieraan kielen ominaisuutta, joista hänen yleislingvistinen tietämyksensä rikastuu.

Kuuluisan altaistimme G. J. Ramstedtin oli tapana väittää, että suomalaisilla kielentutkijoilla on säännöllisesti paremmat mahdollisuudet tajuta oikein esim. sellaisen eksoottisen kielen kuin japanin äänteitä kuin esim. anglosakseilla tai skandinaaveilla, ja hän selitti tämän johtuvan yksinkertaisesti siitä, että suomalaiset ovat jo kotimaassaan oppineet hallitsemaan kaksi niin peräti erilaista fonologista

${ }^{3}$ Kuten tiedetään, Helsingin yliopisto saikin yleisen kielitieteen professuurin syyslukukauden alusta 1966; virka täytettäneen vakinaisesti aikaisintaan $\nabla: n$ 1967 Iopulla. 
järjestelmää kuin suomen ja ruotsin kielen. Tämä seikka oli Ramstedtin mielestä omiaan rikastamaan ja herkistämään tulevan tutkijan foneettista korvaa. Jos tämä pitää paikkansa - ja Ramstedt perusteli käsitystään monin todistein omasta laajasta kokemuspiiristään japanologina -, voimme väittää, että u n k a ri i n perehtyminen avartaa edelleen huomattavasti nuoren suomalaisen foneettista näköpiiriä. Onhan jo pelkästään unkarin konsonanttien määrä niin paljon suurempi kuin suomen, että niiden aritmeettinen suhde on 24:13. Toisin sanoen: suomen konsonanttisten foneemien määrä on vain $54 \%$ unkarin vastaavasta luvusta. Niinpä suomesta ja enimmäkseen ruotsistakin puuttuvat affrikaatat ja liudentuneet konsonantit sekä soinnilliset sibilantit. Suoranaista kielivoimistelua edellyttää esim. tällaisen, József Szinnyein unkarin kieliopissa mainitun lauseen loppuosan ääntäminen: "Inkább éhen halok, hogysem kegyelemkenyeret egyem". Melkoisia ääntämisvaikeuksia ja samalla tietysti taaskin oivallisia tilaisuuksia kielikorvan hiomiseen sisältää sandhiilmiöihin miltei täysin tottumattomalle suomalaiselle perehtyminen unkarin konsonanttien sointiassimila ation sääntöihin ja niiden sovellukseen: hänen on pakko oppia, että nyelvtan ääntyy ñälftån, adhat åthåt, tánczene tāndzzänä, Bécsbe $b \bar{e} d z ̌ b \ddot{a}$, vasgyár våžd'ār jne., vastoin oikeinkirjoitusta.

Unkarin vokalismi sen sijaan ei tarjoa suomalaiselle juuri muuta uutta kuin labiaalistuneen lyhyen $a: n$ ja heleän pitkän $\bar{a}: \mathrm{n}$, ja nekin ovat yleiskielessä vain toistensa kombinatorisia variantteja (allofoneja) eivätkä siis lisää foneemien lukumäärää. Myöskään vokaalien kestokorrela ation runsas fonologinen hyväksikäyttö, joka on unkarin luonteenomaisimpia rakennepiirteitä, ei suomalaiselle opiskelijalle ole mikään outous: sellaiset tavujaksot kuin szegény juhász legény tai rendithetetlenség, jotka esim. ruotsalaiselle tai ranskalaiselle aluksi tuottavat suuria ääntämisvaikeuksia, tuntuvat suomalaisen korvaan varsin kotoisilta. Tällainen sekä pitkän että lyhyen tavun esiintyminen tavuasemasta riippumatta on tunnetusti suhteellisen myöhäinen piirre kummassakin kielessä, sekä suomessa että unkarissa, eikä siis suinkaan mikään vanhan sukulaisuuden todiste. Huvittava kielihistorian paradoksi onkin, kuten tiedämme, että ylen kaukainen sukukieli unkari tästä syystä on prosodisesti suomea lähempänä kuin miltei suomen murteeksi katsottava viro, josta ilmeisesti verrattain myöhäinen germaaninen vaikutus on hävit- 
tänyt kaikki pääpainottomien tavujen pitkät vokaalit (kuten muuten myös suomen omista lounaismurteista). Erinomaisen suurta helpotusta suomalaisille, kuten varmaan kaikille ulkomaalaisille unkarin opiskelijoille, merkitsee se seikka, että kirjakielessä e:llä merkitty lyhyt vokaali nykyisin sallitaan (budapestiläisittäin!) aina ääntää $\ddot{a}: \mathrm{ksi}$, siis ember =/ämbär/ eikä välttämättä /ämber/, nekem = näkäm/ eikä enää ehdottomasti /näkem/ jne. (Sivumennen huomautan, että unkarilaiset puolestaan suomea opetellessaan pyrkivät aluksi soveltamaan samaa liberaalia $\ddot{a}=e$-fonologiaa myös suomeen ääntämällä esim. ämm ä pro emme, häitä pro heitä, mikä ei tietenkään käy laatuun, koska suomessa $\ddot{a}$ ja $e$ ovat jyrkemmin eri foneemeja kuin unkarissa.)

Tapanani on ollut kiinnittää kuulijaini huomiota pariin muuhunkin unkarin ja suomen vokaalien kehitystä koskevaan satunnaiseen samanlaisuuteen, joilla on ollut puhtaasti yleisfoneettiset syynsä eikä mitään vanhaa historiallis-geneettistä yhteyttä. Kuten tunnettua, tutkijat edellyttävät, että unkarin alkuaan kaksitavuisten sanojen toisen tavun avara loppuvokaali $a$ ja $\ddot{a}$ ovat joskus ennen muinaisunkarin aikakautta muuttuneet astetta suppeammiksi $u$ :ksi ja $\ddot{u}$ :ksi: *haza >*hazu,*jänä >>*jägü jne. Näin syntyneet toisen tavun $-u$ ja $-\ddot{u}$ ovat sitten vanhimman turkkilaisvaikutuksen alkamisen jälkeen kadonneet, ja samalla tapahtui ensi tavussa ns. sijaispidennys: *hazu >ház, *jägü >jäa >jég. Edelliseen muutokseen on foneettisesti täysin verrattavissa aunuksen murteiden samanlainen sananloppuinen muutos, esim. $a k k \alpha>a k k u$, pitk $\ddot{a}>$ pitk $\ddot{u}$. Sitä foneettista tosiasiaa taas, että juuri $u$ ja $\ddot{u}$ helpommin katoavat painottomasta asemasta sanan lopussa kuin $a$ ja $\ddot{a}$, valaisevat entisen KaakkoisSuomen murteiden loppuheittotapaukset papu>pap, kyky $>k y k$, kun samoissa murteissa loppu- $a$ ja - $\ddot{a}$ on säilynyt: pata, hätä. Varhaisunkarilaiseen sijaispidennykseen foneettisesti rinnastettava vokaalinpidennys puolestaan on aivan myöhäisinä aikoina tapahtunut alkuaan kolmitavuisissa sanamuodoissa Kaakkois-Suomen murteissa, esim. kannella>kannèl (adessiivi sanasta kansi; vrt. soittimen nimeen kannel), tervasta>tervàst (elatiivi sanasta terva, vrt. nominatiiviin tervas), ja Venäjän-puoleisissa inkeroismurteissa, esim. jumala $>$ jummaal, silmissä $>$ silmiis.

Morfologian ja syntaksin alalla eräät hungarismit muodostuvat suomalaiselle grammaattisesti rikastavaksi elämykseksi. Niinpä 
oman kielemme possessiivisuffiksijärjestelmälle ovat vieraita sellaisetkin seikat, kuin että yksikön ja monikon 3. persoonan suffiksit ovat erilaiset ja että yksi ja useampi omistettava aina, jokaisessa taivutusmuodossa kyetään erottamaan toisistaan. Kuinka vaillinainen suomen omistusliitteistö todella on, näkyy esim. siitä, että yhdellä ainoalla suomen muodolla kätensä on kaikki ne merkitykset, joiden ilmaisemiseksi unkarissa on olemassa seuraavat $\mathrm{y} \mathrm{h} \mathrm{deks} \mathrm{ä} \mathrm{n}$ muotoa: keze, kezét, kezének (a baja), kezei, kezeit, kezük, kezüket, kezeik, kezeiket.

Tavallaan vielä kiintoisampaa on, että omistusliitteiden syntaktinen $\mathrm{k} \ddot{a}$ y t t $\ddot{0}$ unkarissa on kehittynyt morfeemitaloudellisesti suorastaan matemaattisen säästeliääksi. Tarkoitan esim. seuraavanlaisia rakenteita: Gyermeke volt? (suomeksi: = 'Onko hänellä [tai: teillä] ollut lasta?'), Semmijük ninesen (='Heillä ei ole mitään'), Jött értem (='Hän on tullut noutamaan minua'). Viimeksi mainitussa esimerkissä kuvastuu lisäksi se unkarin lauseopin lakonisuutta edistävä piirre, että verbin kolmannenkaan persoonan pronominia ei panna ilmi, jos se on painoton, - siis kuten klassisessa kreikassa ja latinassa. (Suomen kieli on tässäkin kohden valitettavasti eri kannalla.) Huomattakoon edelleen omistusliitteelliset infinitiivit: "Szabad kérdeznem?" (suomeksi: 'Onko minun lupa kysyä?'), 'El kellett menniük" (= 'Heidän täytyi poistua'). Samanlaisia rakenteita tavataan tosin suomessakin harvinaisina murteissa ("Onko kylmäsi?"= 'Onko sinun kylmä?'; 'Mieleni minun tekevi lähteäni laulamahan", Kalevalassa), mutta yleiskieli ei niitä tunne. - Pregnantin ilmaisukyvyn eräänlaisena huippusaavutuksena suomalainen voi pitää sellaista unkarin omistusliitteiden ja omaisuusvartalosuffiksin kasautumaa kuin "az anyámékéi", kömpelösti suomentaen =.äitini sukulaisten omat'.

R a ra avis koko Euroopan kielimaisemassa on verbintaivutuksen kahtiajakautuneisuus subjekti- ja objektikonjugaatioon. Tämä grammaattinen ilmiö on, kuten tiedämme, saanut alkunsa possessiivisuffiksien liittymisestä verbinomineihin, ja jonkinlaisia predispositioita siihen näyttää jo varhain olleen olemassa, koskapa saman kahtiajaon tuntevat myös obinugrilaiset kielet ja mordva. Muille suomalais-ugrilaisille kielille se kuitenkin on yhtä vieras kuin esim. koko indoeurooppalaiselle kielikunnalle. Tässäkin kohden siis sukukielemme unkari avaa suomalaiselle opiskelijalle outoudellaan kiehtovan 
näköalan. Kiintoisinta ei tässä suhteessa tietenkään ole morfologinen puoli (vaikka sekin tarjoaa kokonaisen vyyhden kielihistoriallista problematiikkaa!), vaan subjekti- ja objektikonjugaatioiden syntaksi - osittain suoraviivaisen looginen, osittain helposti ymmärrettävien mutta eri suuntiin häilyvien analogiavaikutusten risteyttämä sääntöverkosto. Kuvaavia meikäläisen mielestä ovat tässäkin tapaukset, joissa näiden konjugaatioiden morfologia on alistettu palvelemaan unkarin syntaksille niin luonteenomaista sanoisinko maskuliinista lakonisuutta: "Ismerek a kávésnak két lányát" ('Tunnen kahvilanomistajan kaksi tytärtä') ilmaisee eri asian kuin "Ismerem a k. k. l." (suomennettavissa: 'Tunnen k:n molemmat tyttäret') ja "Milelt?" ('Mikä sinua vaivaa?', oikeastaan 'Mikä sinut on kohdannut, löytänyt?') sisältää ilmilausumattoman objektin, joka esim. jonkin dialogin lopussa ei voi. olla muu kuin téged; tai: "Elhihetitek, hogy Katiék szívesen látnak" ('Voitte uskoa, että Katin omaiset näkevät sinut mielellään') ilmaisee samoin yksiymmärteisesti, että subjektiivisen konjugaatiomuodon (látnak) objekti (!) on = engem, vaikka se on vain pääteltävissä syntaktisen konstellaation kokonaisuudesta. Tällaisissa ilmaisuteknisesti hienoissa rakenteissa unkarin lauseoppi - niin tuntuu suomalaisesta - muistuttaa tyylikästä runoa, jossa on saatu ilmi enemmän, kuin mitä käytetyt sanat sinänsä merkitsevät.

Suomen kielelle aivan vieras on unkarin kielen harvinaisen ilmaisukykyinen prefiksiverbijärjestelmä. Géza Bárczi sanoo mainiossa 'Unkarin kielen elämäkerrassaan' (A magyar nyelv életrajza): "Verbintaivutuksemme yksinkertaistuminen, näennäinen köyhtyminen on kielemme uudemman ajan historian suurin muutos. Aikaisemman rikasmuotoisuuden ilmeisen vähenemisen korvaa runsaasti — - rikas prefiksijärjestelmä, joka on paljon joustavampi ilmaisuvälineistö kuin sokkeloinen verbintaivutussyntaksi, se kun kykenee niukemmin muotosidonnaisuuksin ilmaisemaan paljon moninaisempia vivahteita kuin verbin tempukset." Tämän prefiksisysteemin opettavuutta suomalaiselle ei vähennä vaan pikemminkin lisää se tosiasia, että se on vain alkuiduiltaan vanhaa ugrilaista perua ja on myöhäisinä aikoina vastaanottanut runsaasti indoeurooppalaista vaikutusta. Onhan tuo ilmaisujärjestelmä täysin sulautunut kielen rakenteen orgaaniseksi perusosaksi ja on oivallinen esimerkki siitä, kuinka hedelmälliseksi vieras grammaattinenkin vaikutus onnellisessa tapauksessa voi muo- 
dostua, kun se pääsee kirvoittamaan ja ikään kuin jalostamaan kielen omia perinnäisiä mahdollisuuksia.

Eteläisimmän suom.-ugr. kielen s a n ast os s a kin on tietysti kaukaa Pohjois-Euroopasta katsellen niin sanoaksemme eksoottiset piirteensä, kuten eräät itämerensuomalaisista kielistä puuttuvat lainakerrostumat: iranilaiset, osseettilaiset, bolgaarilais-turkkilaiset, vieläpä suhteellisen lukuisat kansankieleen asti ulottuvat latinalaiset lainat. Tällaisilla seikoilla on ymmärrettävästi kuitenkin enemmän kulttuurihistoriallista kuin kielen varsinaiseen rakenteeseen ulottuvaa kiinnostavuutta. Mutta poikkeusasemassa on yksi sanastolaji, nim. unkarin kielessä harvinaisen omalaatuinen op pitek oisten u u d is sa n oj en ryhmä. Onhan tosin suomessa - samoin kuin eräissä muissa sivistyskielinä nuorissa kielissä ja suurkielistä saksassa - varsinkin 1800-luvulta lähtien mm. puristisista syistä harrastettu keinotekoista kielenviljelyä. Mutta luulisin, että mistään ei voida osoittaa suhteellisesti, ehkä ei absoluuttisestikaan, yhtä tuloksellista ja yhtä radikaalia tietoista puuttumista kansakunnan kielen kehitykseen kuin on se, mitä edustaa Unkarissa etenkin noin vuosina 1750-1850 melkein kansanliikkeeksi paisunut 'nyelvújítás' ('kielenuudistus'). Tämä reformitoiminta erosi kuten tunnettua esim. vastaavasta suomalaisesta paitsi valtavalta kvantiteetiltaan myös kielen omia perinteitä melko kovakouraisesti kohtelevan radikaaliutensa vuoksi. Se on $\mathrm{mm}$. osoittanut, että tietoinen sanastonkartutus voi edullisissa historiallisissa ja sosiaalis-psykologisissa oloissa onnistua istuttamaan kansakunnan yleiskieleen sellaisten alkukantaistenkin käsitteiden kuin sukulaisuussuhteiden nimityksiä — muistettakoon sanat fivér 'veli' ja növér 'sisar' -, jopa (mikä on vieläkin merkillisempää) uusia persoonapronomineja - ön, önök ('Te'), joiden isä (kreivi Széchenyi) ja syntymävuiosi (1828) tarkalleen tiedetään. 'Tällaiset tosiasiat ovat nähdäkseni periaatteellisesti arvokkaita, ja ne ovat olleet omiaan herättämään teoreettislingvististä mielenkiintoa myös suomalaisten kielitieteen opiskelijain keskuudessa.

Olen näin pitkälti viipynyt unkarin kielen sellaisissa ominaisuuksissa, jotka viehättävät suomalaista opiskelijaa erilaisuudellaan. Mutta, kuten jo sanoin, Helsingin yliopiston puheenaolevan etäsukukielen kurssin tarkoituksena on ensi sijassa kiinnittää huomiota sellaisiin seikkoihin, jotka luovat valoa suomen kielen esihistoriaan. Poimikaamme lopuksi joukko näytteitä sellaisista. 
Tunnettua on, että suomi on muutamissa suhteissa suom.-ugr. kielistä kaikkein konservatiivisimpia. Tämä koskee kuitenkin pääasiallisesti eräitä kohtia sen äännerakenteesta, etenkin vokalismista. Mutta luonnollistahan on, että unkari, puhujamäärältään verrattomasti suurin uralilainen kieli, on puolestaan säilyttänyt paljon sellaista kielikuntamme vanhaa omalaatuisuutta, joka esim. suomesta on joko kokonaan kadonnut tai josta on enää vain jäänteitä jäljellä.

Tuollaisista unkarissa säilyneistä suomalaisugrilaisuuksista on huomioideni mukaan suomalaisille opiskelijoille kaikkein yllättävimpiä ja samalla valaisevimpia adjektiiviattribuutin inkongruenssi: kun unkari sanoo "szép idövel", niin suomi (kuten jokainen muukin itämerensuom. kieli) ilmaisee saman ajatuksen, ikään kuin unkariksi olisi sanottu "széppel idővel" (=kauniilla ilmalla). Onko tämä itämerensuomen kongruenssi omaperäisen kehityksen tulosta vai indoeur. nåapurikielten aiheuttamaa vai ehkä molempien prosessien yhteisvaikutusta, se on vielä lopullisesti ratkaisematon ongelma. Varmaa vain on, että unkari tässä kohden on toiminut uskollisena oman tradition kannattajana. Suomen kielessä kehitys on siis kulkenut päinvastoin kuin esim. germaanisella ja romaanisella taholla alkuperäistä inkongruenssista myöhäsyntyiseen kongruenssiin ja sen oman muotorakenteen kannalta käsitykseni mukaan epätarkoituksenmukaiseen, etten sanoisi epäterveeseen suuntaan.

Toinen unkarin syntaksin ikivanha aito piirre, joka nykysuomelle on tuntematon, on ns. nominipredikaattisuus, siis se seikka, että predikaattina voi olla paitsi finiittinen verbi tietyissä tapauksissa myös substantiivi, adjektiivi tai muukin nomini: "Az apja orvos" ('Hänen isänsä [on] lääkäri'), "Lakásuk elég régi" ('Heidän asuntonsa [on] aika vanha'). Varma todiste siitä, että samanlainen predikaattirakenne on muinoin ollut käytännössä itämerensuomalaisellakin taholla, on nykyisten finiittisten verbimuotojen 3. persoonien palautuminen aktiivin I partisiipin nominatiiviin, esim. tulee $<$ tulevi $<$ tuleva.

Kolmas grammaattinen muinaisperinne, joka unkarissa paremmin kuin suomessa on säilynyt elävänä, on nominien ns. kollektiiviyksikkö. Tunnetaanhan kyllä suomessakin tällainen yksikkö lukusanojen yhteydessä ("sata päivää" = 'száz nap', "monta miest $\ddot{a} "=$ 'sok férfi') ja eräistä parillisista ruumiinjäsenistä puhuttaessa tietyissä tapauksissa ("riisu kengät jalastasi"; huom. myös tyyppi silmäpuoli 'félszemü'). Mutta esim. sellaisissa yhteyksissä kuin "rengeteg ember", "egy pár 
cipo", "öt szál gyertya", "fáj a szemem", "az apja és a anyja haza érkezett" käytetään suomessa nykyisin monikkoa: 'tavattomasti ihmi-

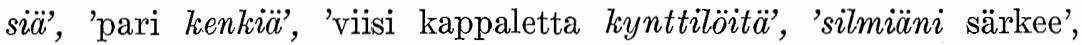
'hänen isänsä ja äitinsä saapuivat kotiin'.

Sellaisetkin ulkomaalaiset, jotka eivät tiedä unkarin kielestä mitään muuta, ovat usein sattuneet panemaan merkille sen heistä kummallisen seikan, että unkarilaisessa tekstissä ihmisen sukunimi sijoitetaan ristimänimen edelle: sanotaan Kovács Ilona eikä Ilona Kovács. Saman tavan piiriin kuuluu, kuten tunnettua, että ammatinnimi tai titteli niin ikään kulkee henkilönnimen jäljessä: Kovács Ilona. gépírónö kisasszony; vastaavasti myös esim. Hatodik Gusztáv svéd király. Suomessa sanotaan konekirjoittaja neiti $I$. K., Ruotsin kuningas Kustaa Kuudes. Tässä asiassa unkarin kieli tunnetusti taas noudattaa ikivanhaa omaperäistä sanajärjestyssääntöä, jonka mukaan attribuutti käy pääsanansa edellä. Ns. ristimänimihän on historiallisesti katsoen ihmisen varsinainen nimi, johon ns. sukunimi on liittynyt vain lisämääritteenä. (Muinaisina aikoina kullakin ihmisellä on normaalitapauksessa ollut yksi ainoa nimi.) Sanaliitossa Kovács gépŕrónő pääsana on ammatinnimi ja sukunimi vain sen lisäselityksenä. Suomessa (kuten sivumennen sanoen myös Virossa) kansanmurteet ovat säilyttäneet osittain saman perinnäisen sanajärjestyssäännön, joten unkarin kielessä vallitseva tapa saattaa suomalaisesta tuntua suorastaan kotoisen tyylikkäältä. (Vrt. Kustaa-kuningas, Kauppis-Heikki yms.) Samaa on sanottava unkarissa yleisestä tavasta ilmaista myöntävä vastaus toistamalla kysymyksessä esiintynyt painollisin sana: "Haza mégy? — Haza!"='Kotiinko menet? Kotiin!' Tässä tapauksessa unkarin lauseoppi osaltaan siis vain vahvistaa suomalaiselle sen tiedon, että puhe on kummankin kielen vanhasta yhteisperinnöstä.

Kielitieteen vankkana selkärankana on yhä vielä äännehistoria ja siinä nimenomaan konsonanttien historia. Juuri tällä alalla unkarin kielessä on tallella monta arvokasta kriteeriä vertailevan tutkimuksen hyödyksi. Saanen tässä lyhyesti viitata niistä muutamiin yleisesti tuttuihin asioihin.

Suomen kota, käsi (käte-) ja vetää-sanoja vastaavat vanhat sukulaissanat unkarissa kuuluvat ház, kéz ja vezet, mutta sanoja pato, esi- (ete-) ja ydin (ytime-) unkarin fal, el (elö-) ja velö. Sanansisäisenä konsonanttina on siis suomessa kummassakin ryhmässä ns. 
vahvassa asteessa $t$, unkarissa edellisessä ryhmässä $z$ ja jälkimmäisessä ryhmässä $l$. Lapin kielessä on kaikissa edellisen ryhmän vastineissa kuten suomessakin vahvassa asteessa $t$-äänne mutta jällkimmäisen ryhmän sanoissa vahvassakin asteessa spirantti $\delta(\delta)$. Tällainen säännöllisyys, että unkarin z:tä tällaisissa tapauksissa aina vastaa lapin

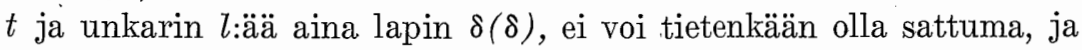
kun on otettu huomioon vielä muidenkin suom.-ugr. kielten äänneedustus samojen sanojen etymologisissa vastineissa, on päädytty siihen erittäin vahvasti perusteltuun selitykseen, että suom.-ugr. kantakielessä on ház-tyyppisissä sanoissa ollut sanansisäisenä konsonanttina * $t$ mutta fal-tyyppisissä sanoissa * $\delta$. Näin ollen unkarin kieli on säilyttänyt, vaikkakaan ei alkuperäisiä äänteitä, kuitenkin ikivanhan kahtalaisuuden, mutta suomi on sulattanut yhteen nuo kaksi alkuaan erilaisten konsonanttien edustusta. Saadakseen siis tietää jostakin kota- tai pato-tyyppisestä sanastaan, kumpaan alkuperäiseen ryhmään se kuuluu, suomen kielen tutkijan on turvauduttava paitsi lappiin nimenomaan juuri unkarin kieleen.

Samantapaista erilaisuutta unkarin ja suomen vanhojen perinnäissanojen äännerakenteessa on todettavissa enemmänkin. Niinpä suomen $s$-alkuisia sanoja silmä, suu ja sydän vastaavat unkarissakin s-alkuiset szem, száj ja szív, mutta suomen sanoja syli, suoni ja syö unkarissa $s$ :ttömät öl, in ja $e$-szik. Selitys, jota eksaktisemmin vakuuttavaa missään humanistisessa tieteessä tuskin voidaan vaatia, on taaskin se, että suomalais-ugrilaisessa kantakielessä on edellisen ryhmän sanoissa ollut liudentunut *ś, jälkimmäisen ryhmän sanoissa liudentumaton *s-. Unkari on siis jälleen säilyttänyt kahtalaisuuden, kuitenkin siten, että liudentunut ${ }^{*} s^{-}$on vain menettänyt liudennuksensa mutta liudentumaton *s- on kokonaan kadonnut. Suomessa siis molemmat sibilantit ovat langenneet yhteen, joten niiden välinen ero on hävinnyt. - Liudentumattoman ja liudentuneen dentaalinasaalin eron unkarin kieli sen sijaan on säily:ttänyt monissa tapauksissa sellaisenaan, kun nuokin äänteet suomessa taas ovat langenneet yhteen. Verrattakoon esim. sellaisia sanapareja kuin név: nimi, négy: neljä, néz: näkee; fon: punoo, in: suoni, menö: menee ja toisaalta nyíl: nuoli, nyal: nuolee, nyel: nielee; könny: kyynel, könyök: kyynärä, meny: minï̈.

Ja vielä yksi näyte siitä, kuinka suomesta (kuten yleensä itämerensuomesta) kokonaan kadonnut konsonantti on pienin muutoksin 
säilynyt unkarissa: suomen jää, pii, hïri: unkarin jég, fog, egér. Varsinkin obinugrilaisten ja volgalaiskielten perusteella on pääteltävissä, että alkuperäinen nasaalikonsonantti *- $\boldsymbol{\eta}$ - on unkarissa muuttunut homorgaaniseksi oraaliklusiiliksi $g$ :ksi ja varhaiskantasuomessa kahden vokaalin välistä kokonaan kadonnut.

Olen täten esittänyt joukon tekemiäni huomioita siitä, mitä etua unkarin kielen rakenteen pääpiirteittäisestä tuntemisesta saattaa olla suomalaiselle äidinkielen opiskelijalle puhtaasti lingvistiseltä kannalta. Kokonaan koskettelematta olen jättänyt asian kulttuuripoliittisen puolen. Lopuksi muutama sana siitäkin.

Kun Helsingin yliopistossa niinkin suuri opiskelijamäärä kuin mainitsin vuosittain ottaa osaa unkarin kurssiin ja kun tätä lukua vielä lisää vastaavanlainen toiminta Turun Yliopistossa (jossa muuten vuodesta 1964 lähtien on olemassa myös suom.-ugrilaisen kielitieteen oppituoli) ja Jyväskylän korkeakoulussa (nykyisessä yliopistossa), on aihetta kysyä, onko tuommoisesta alkeiskurssin suorittaneiden kaaderista noussut esiin myös vaativampaa kielitaitoa tavoittelevia yksilöitä. Mitään tilastoa ei ole käytettävissäni, mutta henkilökohtainen käsitykseni on se, että vaikka muutamia tuollaisia tapauksia onkin todettavissa, ne eivät varmaankaan ole oikeassa suhteessa alkeiskurssin opiskelijain lukumäärään etenkään nuorempien ikäluokkien kohdalla. Meillä on nimittäin aivan liian vähän sellaisia unkarintaitajia, jotka pystyisivät toimimaan esim. kaunokirjallisuuden pätevinä suomentajina. Tärkein syy tähän epäkohtaan on tietysti ollut toinen maailmansota, joka erilaisine seurauksineen on liian kauan jarruttanut Unkarin ja Suomen keskinäisiä kulttuuriyhteyksiä. Onhan luonnollista, että suomalaisen on varsinainen, riittävän syvällinen unkarintaito hankittava oleskelemalla kyllin kauan unkarilaisessa ympäristössä. Kuten tiedämme, kummankin maan viranomaiset ovat viime vuosina ilahduttavasti edistäneet maidemme välistä stipendiaattien vaihtoa. Tätä tietä ja - lisättäköön - helpottamalla myös yksityisyritteliäisyyteen perustuvaa oleskelua sukulaismaassa toivottavasti päästään siihen, että Suomessa jo lähivuosina olisi vaikkapa kymmenkunta sellaista epävirallista ja aktiivista unkarin kielen ja unkarilaisen kulttuurin tuntijaa, jotka omakohtaisesta harrastuk- 
sesta kukin osaltaan huolehtisivat nykyistä paremmin Unkarin korkeatasoisen kirjallisuuden tutustamisesta maassamme. Jos vaatimaton yliopistollinen unkarinopetuksemme voi välillisesti auttaa tällaisen tavoitteen saavuttamista, silloin sen vaikutus kansakunnan elämään on ulottunut laajemmallekin kuin vain oppikouluväen ja tieteenharjoittajain piiriin.

Kuinka paljon yksi ainoakin todella innostunut, lahjakas ja tarmokas kulttuuripersoonallisuus voi tällaisten kahden kansan välisien kosketusten alalla saada positiivista aikaan suurenkin yleisön keskuudessa, sen on meillä jo kolmisen miespolvea sitten esimerkillisellä tavalla osoittanut Unkarin ja Suomen suhteiden aikakirjoissa aina muistettava Antti Jalava.

\section{LaURI HaKUlinen: $\ddot{U} b e r$ den ungarischen Sprachunterricht an den finnischen Universitäten}

Der Verfasser bringt eingangs einige geschichtliche Angaben über das Interesse finnischer Linguisten für die ungarische sprache und erwähnt dabei neben den seit 1926 als Universitätslektoren in Helsinki tätigen gebürtigen Ungarn den ausserplanmässigen Lektor Antti Jalava (1880-1909) als erfolgreichsten Förderer einer Kenntnis des Ungarischen. Seit 1957 liegt auch an der Universität Turku der ungarische Sprachunterricht in den Händen eines gebürtigen ungarischen Lektors. Man ist von jeher der Ansicht, dass die Hauptziüge dieser mit dem Finnischen nur entfernt verwandten Sprache einem angehenden Finnischlehrer vertraut sein sollten und ausserdem ihm nützlich seien, weil durch deren Kenntnis gewisse Vorstufen des finnischen Sprachbaues erhellt würden. Von besonderem Gewicht sind in dieser Hinsicht z.B. auf dem Gebiete der Syntax die Inkongruenz von Adjektivattribut und Hauptwort, die Position eines Substantivattributes vor seinem Hauptwort auch in Fällen, wo es sich um die Beziehungen zwischen Vor- und Nachname oder von Berufsbezeichnung und Titel zum Nachnamen handelt; zu nennen sind noch die Anwendung des Nominalprädikats sowie der häufigere Gebrauch des sogenannten kollektiven Singulars. In der Lautlehre hat das Ungarische im Vergleich mit dem Finnisehen ursprünglichere Züge bewahrt; z.B. hat sich dort die aus der finnischugrischen Ursprache stammende getrennte Vertretung des $t$ und $\delta$ im Wortinneren erhalten, desgleichen das Auftreten mouillierter und unmouillierter Konsonanten. Weiterhin ist zu beachten, dass das intervokalische $\eta$, das im Finnischen spurlos verschwunden ist, im Ungarischen durch den homorganen Klusil $g$ vertreten wird. - Der Verfasser hebt ganz besonders den Umstand hervor, dass einige vom Finnischen a bw e i chen de Züge des ungarisehen Sprachbaues dazu 
beitragen, den allgemeinlinguistischen Blickwinkel der finnischen Studenten zu erweitern. Als solche Züge führt er an: den Konsonantenreichtum des Ungarischen (die Anzahl der ungarischen Konsonanten im Verhältnis zu den finnischen ist 24:13), die Bedeutung der Sandhi-Erscheinung in der ungarischen Phonetik, die unvergleichbar grössere Vollkommenheit des Possessirsuffixsystems und die weiter fortgeschrittene Entwicklung der syntaktischen Verwendung dieser Suffixe, sowie schliesslich auf dem Gebiet der Syntax und der Morphologie die der finnischen Sprache (gleichwie auch den idg. Sprachen) völlig fremde objektive und subjektive Konjugation. 